\title{
Gender Differences and Family Reunion in the European Union: Implications for Refugees
}

\author{
Eleonore Kofman and Rosemary Sales
}

\begin{abstract}
The feminization of immigration flows into Europe, both through family reunion and the independent migration of women, has been one of the most significant social changes of the past two decades. This development has, however, remained largely unexplored. This paper examines the consequences of changes in access to family reunion, and its gendered implications for women entering as family migrants and as applicants to sponsor family members. It calls for a positive evaluation of immigration policy aimed at securing rights as well as controlling immigration flows.
\end{abstract}

\section{Précis}

La féminisation du flux migratoire vers l'Europe, du aux réunifications successives de familles ou à l'immigration indépendante des femmes, a été l'un des changements sociaux les plus significatifs des deux dernières décennies. Cependant, ce développement est demeuré largement inexploré. Le présent article examine les conséquences des changements dans l'accessibilitéà la réunification familiale et leurs implications pour les femmes entrant comme immigrantes pour raisons familiales, ainsi que pour les femmes envisageant de parrainer des membres de leurs familles candidats à l'immigration. Un appel est fait pour une évaluation positive des politiques $d$ 'immigration visant d̀ préserver les droits autant qu'à contrôler le flux migratoire.

The feminization of immigration flows into Europe has been one of the most

Eleonore Kofman, Ph.D., is Professor of Geography at Nottingham Trent University, Nottingham, United Kingdom.

Rosemary Sales, Ph.D., is Principal Lecturer in the School of Social Science at Middlesex University, London, United Kingdom. significant social changes of the past two decades. The mass post-war labour migrations into Europe had been mainly of single people and were predominantly male, although in some instances (for example the Irish to Britain) women outnumbered men. With the onset of recession in the mid 1970s, most European states ended mass primary labour immigration. Family reunification was eased in countries where it had previously been more restrictive, contributing to the feminization of immigrant flows and the permanent settlement of immigrant populations. Apart from undocumented migrants and asylum seekers, European immigration has been heavily female since the mid-1970s. An estimated six million third country nationals, of whom 45 percent were women, had right of residence in the European Union (EU) in 1990 (Castles and Miller 1993). Adding the four million who have acquired citizenship, together with undocumented workers, gives a population of at least five million women from third countries.

Since the 1970s, ever more stringent attempts have been made to end immigration, deter the arrival of newcomers with the right of entry, and encourage immigrants to leave. Although the opening of East-West borders has led to new forms of guestworker migration to a reunited Germany (Morokvasic 1993; Rudolph 1996), the main source of immigration into Western Europe in the past twenty years has been family formation and reunion. Excluding asylum seekers, it accounted for the overwhelming majority of legal immigration to Belgium and Germany throughout the 1980s, and was the major source of permanent settlement in France and the United Kingdom. In tightening the conditions of entry and subjecting family formation and reunification of part- ners and children to more rigorous restrictions, the objective has been to impose greater control on migration flows and contain the reproduction of immigrant communities.

The early 1990s also witnessed a dramatic increase in the numbers of asylum seekers in Europe. In the period 1983-1994 applications totalled almost 4.5 million, increasing from 70,0001983 to a peak of 702,000 in 1992 (Salt 1995). Approximately 80 percent of asylum applications in Europe come from men. This results partly from the male majority in many refugee flows, since men are considered the main applicant in a joint application, while women are often rendered invisible in the statistics. It also reflects the difficulties women have had in being accepted as refugees in their own right (Crawley 1997). Asylum granting authorities are more ready to accept men as political actors, and they therefore have a higher chance of being granted Convention Status. Women on the other hand are more likely to be granted some form of residence status on humanitarian grounds, ${ }^{1}$ which brings fewer social rights.

The sharp increase in asylum seekers, together with German unification and the breakdown of state structures in Eastern Europe brought the issues of immigration and asylum to the fore in the 1990s, especially in Germany and Austria, precipitating measures to restrict entry at state and supra-national level. European integration has brought moves to harmonize immigration and asylum policy across the European Union, sharpening the distinction between the rights of citizens and non-citizens, and between legal and undocumented residents (Kofman and Sales 1992). Increasingly draconian policies against immigrants and asylum seekers have been developed by inter-governmental institu- 
tions such as Schengen and agreements made under the Maastricht Treaty.

Individual governments have implemented their own restrictions. Refusals and deportations have increased dramatically across Europe. In Britain, for example, refusals were 2025 percent of decisions in the 1980s, increasing to over 80 percent in 1996, with grants of asylum down to 6 percent (Home Office). Detentions of asylum seekers have also increased (Joint Council for the Welfare of Immigrants [JCWI] 1997, 86). These measures have been effective in deterring asylum seekers, bringing a fall of more than a third in applications between 1995 and 1996. In France mass deportations have taken place using specially chartered airlines.

Despite the convergence of policies on control of entry, the incorporation and integration of immigrants and race relations remains largely within the domain of "subsidiarity," that is the remit of individual member states. The European Commission and Parliament have attempted to pursue a more positive role in securing the rights of migrant workers and asylum seekers (JCWI 1994a), basing their recommendations on a series of European and international conventions.

Family reunion is considered by some to be one of the most basic rights, derived from general principles of human rights (Baubock 1991). The Universal Declaration of Human Rights (1948) included an article on the right to marry and found a family. The 1990 UN Convention on the Protection of the Rights of All Migrant Workers and Members of Their Families encouraged family reunion but left it to the goodwill of states to implement (Hune 1991). In all European states, however, legal migrant workers must meet stringent conditions before being given permission to bring in close family members. Some cases have been brought to the European Court of Human Rights on the basis of Article 8 (i.e., respect for private and family life) of the European Convention of Human Rights which, unlike other European conventions, encompasses nationals and non-nationals. A recent decision tipped the balance in favour of state immigration control and against family life: the court concluded that the location of a family in two states does not present an insurmountable obstacle to the pursuit of family life, and that the potential for breaches of immigration law favours exclusion of family members (JCWI 1996, 9).

None of the main instruments concluded for the protection of refugees guarantees the principle of family reunification (Plender 1991, 372). Most European states, however, grant it virtually unconditionally to those with full refugee status or to people displaced from conflict zones deemed "special cases." As the number of grants of Convention status diminishes, a growing proportion of asylum seekers are enduring long separation from their families. Refugees granted some form of humanitarian status, as well as those awaiting a decision or appealing against refusal, have extremely limited and conditional rights to family reunion. As increasingly stringent conditions are placed on those applying for family reunion, the impact is likely to be felt most severely by women asylum seekers whose vulnerable legal and economic status places immense obstacles to meeting the requirements.

\section{Family Reunion and Formation}

Family reunification refers to members of a family joining a settled migrant while family formation involves a noncitizen spouse joining a citizen. Of all immigration policies, it is the most explicitly gendered in its principles and application. State policies have generally assumed relationships of dependency between female migrants and the husband or fiance they are joining, viewing the man as breadwinner. Restrictions on their rights in the initial years of residence, which vary between states, may make it more difficult to gain an independent legal and social status in subsequent years. Limitations on the right to work and access to welfare force many into casualized and exploitative work situations.

Despite its numerical significance, there has been little theoretical, policyoriented or statistical analysis of this form of migration. Admittedly, focusing on this issue could lead to demands for even more restrictive measures on the grounds that family reunification is one of the few remaining avenues available for immigration. The silence on this area is, however, more likely to be a result of the tendency by mainstream theorists to marginalize female-dominated forms of international migration. The prevailing attitude has been that men produce and women reproduce. In this view, women migrate to join men as wives and dependents and their participation in the labour market is secondary (Kofman 1997). Hence, as Morokvasic (1984) commented over a decade ago, there is no need to question or probe more deeply the reasons for female migration.

Academic literature is slowly beginning to investigate the issue of family reunification (Lahav 1996). France is the only state to have commissioned in-depth and large-scale research on the family formation of immigrants from different backgrounds (Silberman 1991; Tribalat et al. 1991; Tribalat 1996), as well as smallscale studies of the experiences of those bringing in members (Hu Khoa and Barou 1996). These studies have exposed changing patterns of male migration, i.e. as migration has become more risky with increasing numbers of undocumented migrants and asylumseekers, it has tended to select single men. Many groups continue to favour bringing in wives from their home country; for example, 80 percent of single Turkish men seek wives in Turkey.

The research also reveals a growing male component in family reunification flows, as women (whether as independent labour migrants, second and third generation migrants, or refugees and asylum seekers) apply to bring in family members. This is particularly important among those groups who seek spouses in their 
countries of origin. British statistics also reveal a growing masculinization of family reunion flows from the Indian sub-continent and Africa (Home Office).

The European Year of the Family ironically coincided with an inter-governmental meeting of the European Union in June, 1993 which adopted highly restrictive resolutions on family reunion. Though not binding, these will tend to be incorporated into national legislation. The definition of the family is restricted to spouse and dependent children, while applications for family reunion must be made outside the receiving state i.e. regularization outside the procedures is excluded (JCWI 1994a, 25-26). This runs contrary to the Report of the Committee on Civil Liberties and Internal Affairs of the European Parliament (European Parliament 1992) which reminded states of their obligations emanating from international conventions, and urged them to take no action which would render these rights devoid of substance (JCWI 1994a, 24).

Those included within the definition of "family" for immigration purposes varies between states. Only the United Kingdom ${ }^{2}$ and the Netherlands allow non married heterosexual partners to enter. The Netherlands and the Scandinavian countries recognize homosexual relationships in their immigration legislation. Some gay couples have been admitted under exceptional grounds in Britain. According to the campaigning group Stonewall, by Autumn, 1996, seventeen gay men had been allowed to stay on the basis of a homosexual relationship. These remain, however, minor exceptions to rules which generally impose legal marriage as a condition. Helma Lutz (1994) points out the differential standards involved:

While over the last three decades, European legislation has taken into account the radically changing role patterns between spouses by legally equating cohabitation with marriage, in the case of immigrants, the situation is the reverse: marriage has become, more than ever, the backbone of legal entrance to the EU.

Legislation on freedom of movement entitles EU nationals resident in another member state to bring in their family, including spouses and children who are non-citizens. There is no such right for EU nationals resident in their own country, where national rules on family reunion apply. Some states, including Germany, Italy and France, grant their own nationals the right to bring in foreign spouses, although in the latter case, even this form of marriage is coming under more active surveillance. In others, including the Netherlands and Britain, spouses of nationals must meet the same stringent criteria as those of foreign nationals.

No EU state provides the automatic right for migrants with right of residence to bring their families to join them. While all recognize marriages contracted abroad, conditions for the entry of spouses and other dependants vary considerably (JCWI 1994a; JCWI 1994b). In Germany, for example, a migrant man (including non-citizens born in Germany) can only get an entry permit for a wife if he has lived in Germany for at least eight years before marriage, and if the marriage has already existed for at least one year. This illustrates the double standard in treatment of migrant families, since the condition forces the couple to live apart for a year, a period of separation which German divorce legislation takes as an indicator of marital breakdown (Polzer 1995). In Britain the Conservative government introduced the "primary purpose rule" under which spouses must demonstrate that the main purpose of marriage is not immigration. It was not enough to show that the marriage was genuine, or even that the couple had produced children. ${ }^{3}$ The rule has been racially targeted at spouses from Third World countries (JCWI 1997). The Labour government, elected in May 1997 has declared its intention not to use the rule in most cases. It is not yet clear what impact it will have on groups such as those from the Indian sub-continent, where 70 percent of whose applications are currently turned down.

In many European states, it has become more difficult for fiancés to gain entry, as marriages are viewed with increasing suspicion as a means of gaining immigration status. In France, the period of dependence for spouses has been reduced, but fiancés have to face a longer period before gaining independent rights. Where the future spouse's residency conditions require extension, they are increasingly forced to leave the country to apply for a valid visa and are not certain of being granted one.

All states with the exception of Belgium make entry conditional on the applicant's ability to maintain the family out of his or her own resources from employment or business, and all require the applicant to demonstrate that they have adequate housing. French research shows that this is the most difficult obstacle (Tribalat 1996). It is likely to become more onerous as the applicant must now provide a living standard equivalent to the French norm which is precisely measured for each adult and child occupying the residence. These new regulations do notallow the inclusion of family allowances as part of income, thereby targeting families wanting to bring in children. It is more difficult for a woman to show that she can support a partner without recourse to public funds, particularly if she has children, since women generally earn less than men and immigrant women less than nationals (Harzing 1995). Women applicants have generally had to rely on their extended family to provide accommodation and income to meet the legal requirements.

All states impose a period during which the spouse is dependent for residence status on the partner. This varies from one to three years, although in Spain, the socialist government introduced a rule making it indefinite. During this time, the dependent spouse is liable to deportation if the marriage breaks down. It can mean that women are tied to failing, and sometimes violent, marriages in order to maintain 
their right of residence and that of their children. A report for the Newham Asian Women's Project (1993) in London claimed that the "one year rule" has become a tool of control which can be used to threaten vulnerable women. According to the group Southall Black Sisters (SBS), which campaigns against this rule in Britain, in the eighteen months to July 1995,755 women were threatened with deportation because of marriage breakdown, of whom 512 were fleeing domestic violence (SBS 1997).

Most states grant the right to work to family members entering as dependants. Ireland, however, refuses to grant preferential right to work for family members nor is it automatic in Spain. Germany has allowed it since the Aliens Act of 1991 was passed by the German parliament, but the issue of a work permit is conditional on the state of the labour market. During the period of "probation," spouses are not entitled to claim benefits or have "recourse to public funds." This reinforces dependency, forcing many women into illegal work.

Women asylum seekers face particular problems in bringing in family members. With convention status now granted in a tiny minority of cases, many have insecure legal status. Most European states offer some form of residence on humanitarian grounds to asylum seekers who they determine do not meet the criteria of the convention, but for whom it would be unsafe to return. This status is known as Exceptional Leave to Remain (ELR) in Britain; or Duldung (tolerated residence) in Germany. The social rights attached to this status vary, as does the period and security of residence permitted. There is, however, no general right to bring in families, and immediate family reunion is generally offered only in extremely limited cases. Finland, which grants a tiny number of convention statuses, and Sweden are the only countries which allow it unconditionally. In other states, refugees must wait for a period of stipulated residence, for example, in Britain it was four years, after which they may apply on the same

Table 1: Family Reunification and Formation in France, 1990-1995

\begin{tabular}{lcccc}
\hline Year of Entry & $\begin{array}{c}\text { Family } \\
\text { Reunion }\end{array}$ & $\begin{array}{c}\text { Spouse of } \\
\text { French } \\
\text { Citizen }\end{array}$ & $\begin{array}{c}\text { Parent of } \\
\text { French } \\
\text { Child }\end{array}$ & $\begin{array}{c}\text { Family of } \\
\text { Refugee }\end{array}$ \\
\hline 1990 & 36,949 & 15,254 & 3,080 & $3,200 *$ \\
1991 & 35,625 & 18,763 & 3,146 & 1,246 \\
1992 & 32,665 & 19,045 & 2,986 & 1,065 \\
1993 & 32,421 & 20,062 & 2,834 & 1,778 \\
1994 & 20,645 & 13,145 & 1,749 & 776 \\
1995 & 14,360 & 13,387 & 1,921 & 749 \\
\hline
\end{tabular}

* Likely to be an overestimation.

Source: Tribalat (1996; 1997).

basis as legal migrant workers. These conditions often pose insuperable barriers to refugees, few of whom are able to find secure employment in their country of exile (Liebaut and Hughes 1997). Women, particularly those with children, are least likely to be employed, and are unlikely to be able to call on extended family networks in order to support them in meeting the criteria.

The pattern of change in family reunion policy in the 1990s has been uneven. While Denmark increased the period of residence for the spouse in 1992 and restricted rights of parents to join children, others such as Germany eased some requirements in the early 1990s. In general, immediate access to employment for those joining a migrant with long-term residence status has been eased. The continuing importance of formal citizenship status was, however, starkly illustrated in January 1997, when the German government introduced new visa requirements for foreign children of resident migrants travelling to Germany to visit relatives (The Guardian 1997). Overall, the imposition of more demanding conditions for family reunification and formation are likely to reduce the numbers entering under this category. French statistics certainly confirm the efficacy of such changes in legislation from 1993 to 1995 (Table 1).

\section{Conclusion}

European integration has created a momentum towards ever tighter restrictions on the entry of outsiders, a project eagerly taken up by many state and regional authorities within the European Union. The recent intervention of the EU to harmonize conditions of access to family reunion of Third country nationals is in general producing minimum common-denominator guidelines. As "traditional" family structures in Europe increasingly break down with more women becoming economically independent of men and more people living outside marriage relations, immigration rules have enforced an ever stricter adherence to formal marriage as the basis for migration. Attempts to derive principles of family reunion from international conventions on the right to family life have been subordinated to obsessive concerns to control immigration and secure state borders. Immigration policies in Europe in the past two decades have been based largely on the assumption that immigrants are a problem to be kept out if at all possible, and to be allowed in only in exceptional circumstances.

Many refugees and migrant women have become active in campaigning with others within Europe to challenge these rules which undermine their independence. The most urgent issue is 
to end women's dependence for residence status on husbands, which creates and reinforces unequal relations of power and often abuse and violence. There also needs to be a deeper understanding of the changing conditions of family reunion and its gender dimensions. Refugee women in particular face immense difficulties in accumulating the ever more substantial resources necessary to bring in family members. Whilst a number of comparative European studies have sought to render the issues facing black and migrant women more visible, and in giving them a voice (Hoskyns 1996), the European Union's policies on sexual discrimination have paid little attention to black and migrant women.

Our discussion in this paper has concentrated on the gendered conditions of entry to European states. Clearly these conditions have major implications for women's access to social, political and economic rights within Europe. Recent changes in government in France and the United Kingdom have brought some respite in the barrage of repressive legislation targeting family migrants and asylum seekers. It is likely that within the next few years there will be increasing alignment of the rights of long-term legal non-nationals with those of European citizens. However valuable a Charter of Immigrant Rights (Migrants' Forum 1987) including a wider right to family reunion may be (Moulier Boutang 1993/94), it leaves the plight of the undocumented and insecure unresolved. It is unlikely that major legislative changes will be implemented without a far more positive evaluation of immigration, which would recognize the contribution of immigrants to economic, social, political and cultural life in European, and be based on securing rights as well as controlling immigration flows.

\section{Notes}

1. Unpublished information from the British Home Office.

2. This was rescinded in 1995.

3. The existence of children was allowed as proof of the genuineness of the marriage from 1992.

\section{References}

Baubock, R. 1991. "Immigration and the Boundaries of Citizenship." Monograph in Ethnic Relations, no. 4, CRER, University of Warwick.

Castles, S., and R. Miller. 1993. The Age of Migration: International Population Movements in the Modern World. London: Macmillan.

Crawley, H. 1997. Women as Asylum Seekers: A Legal Handbook. London: Immigration Law Practitioners' Association and Refugee Action.

The Guardian. 1997. "Bonn Cracks Down on Foreigners," 16 January.

European Parliament. 1992. Report of the Committee on Civil Liberties and Internal Affairs of the European Parliament. Strasbourg: European Parliament.

Harzing, A-W. 1995. “The Labour Market Position of Women from Ethnic Minorities: A Comparison of Four European Countries." In Women and the European Labour Market, edited by A. Van DoorneHuiskes. London: Paul Chapman.

Home Office. (various dates). "Asylum Statistics United Kingdom." Home Office Statistical Bulletin. London: Home Office.

Hoskyns, C. 1996. Integrating Gender. London: Verso.

Hu Khoa L., and J. Barou 1996. “Connaissances et usages du dispositif d'acceuil par les familles regroupées". Migrations Etudes, no. 68

Hune, S. 1991. "Migrant Women in the Context of the International Convention on the Protection of the Rights of all Migrant Workers and Members of Their Families." International Migration Review 25, no. 4, 800-17.

Joint Council for the Welfare of Immigrants (JCWI). 1994a. The Right to Family Life for Immigrants in Europe. London: JCWI.

_. 1994b. "Family Reunion Policies in Six European Countries." EuroBriefing, no. 1. . 1996. "Human Rights Disasters." JCWI Bulletin.

-1997. Immigration, Nationality and Refugee Law Handbook: A User's Guide. London: JCWI.

Kofman, E. 1997. "'Female Birds of Passage' a Decade Later: Gender and Immigration in Europe." International Migration Review (forthcoming).

Kofman, E., and R. Sales. 1992. "Towards Fortress Europe?" Women's Studies International Forum 15, no. 1, 29-39.

Lahav, G. 1996. “International vs. National Constraints in Family Reunification Migrant Policy: A Regional View from Eu- rope." Paper presented at the Annual Conference of International Studies Association, San Diego, April 1996.

Liebaut F., and J. Hughes. 1997. Legal and Social Conditions for Asylum Seekers and Refugees in Western European Countries. Copenhagen: Danish Refugee Council.

Lutz, H. 1994. "Obstacles to Equal Opportunities in Society by Immigrant Women with Particular Reference to the Netherlands, the United Kingdom, German and the Nordic Countries." Prepared for Joint Special Group on Migration, Cultural Diversity and Equality of Women and Men.Strasbourg: European Commission.

Migrants' Forum. 1987. Charter of Immigrant Rights. Strasbourg: Council of Europe.

Morokvasic. M. 1984. "Birds of Passage Are Also Women." International Migration Review 18, no. 4, 886-907.

_. 1993. "In and out of the Labour Market: Immigrant and Minority Women in Europe." New Community 19, no. 3, 459-84.

Moulier Boutang, Y. 1993/94. "Pour un statut constitutionnel et européen de l'immigration". Plein Droit 22, no. 3, 48-55.

Newham Asian Women's Project. 1993. Annual Report. London.

Plender, R. 1991. International Migration Law. 2nd ed. Dordrecht: Martinus Nijhoff Publishers.

Polzer, C. 1995. "Country Profile: Germany." Confronting the Fortress, edited by European Women's Lobby. Brussels: European Commission.

Rudolph, H.1996. “TheNew GastarbeiterSystem in Germany." New Community 22, no. $2,287-300$.

Salt, J. 1995. "International Migration Report." New Community 21, no. 3, 443-64.

Silberman, R. 1991. "Regroupment familial: ce que disent les statistiques". Hommes EMigration 1141, 13-17.

Southall Black Sisters (SBS). 1997. The One Year Rule. London: SBS.

Tribalat M. et al. 1991. Cent Ans d'Immigration: Etrangers d'Hier, Français aujourd'hui. Travaux et Documents, Cahiers no. 131. Paris: INED.

Tribalat M. 1996. “Chronique de l'immigration". Population 52, no. 1, 141-96.

Tribalat M. 1997. "Chronique de l'immigration: les populations d'origine étrangère en France métropolitaine". Population 53, no. 1, 163-220. व

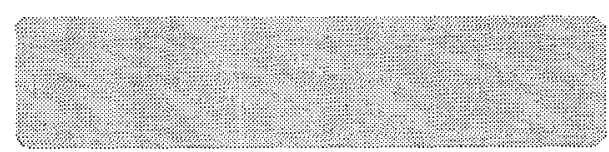

